\title{
CD4 T cells in the rheumatoid joint are oligoclonally activated and change during the course of disease
}

\author{
Hossein Ali Khazaei, Claudio Lunardi, Alex K So
}

\begin{abstract}
Objective-To assess the nature of $T$ cell receptor (TCR) utilisation by CD4 T cells in the rheumatoid joint.

Methods-Sequencing of the joining (NDJ) region of TCR $\beta$ chain mRNA isolated from synovial fluid CD4 $T$ cells was performed in three patients in order to determine if oligoclonal expansion of particular sequences was present. Two patients were studied longitudinally to determine if these sequences changed over time.

Results-A number of dominant clonotypes were found within the TCR transcripts sequenced in each patient. In the two patients who were studied longitudinally, different dominant clonotypes were detected over time. No single clonotype was persistently dominant during the period of study.

Conclusions-The pattern of TCR usage showed multiple oligoclonally expanded CD4 $T$ cells within the rheumatoid joint. The change in clonotypes within the joint over time suggests that different antigens may be able to elicit synovial inflammation during the course of rheumatoid disease.
\end{abstract}

(Ann Rheum Dis 1995; 54: 314-317)

The aetiology of rheumatoid arthritis (RA) remains unknown. A key role for $\mathrm{T}$ cells has been proposed, based on their activated phenotype within the rheumatoid synovium, ${ }^{1}$ the strong association with HLA-DR antigen polymorphism, ${ }^{2}$ and the clinical response to therapies directed against $T$ cells. However, the nature and mechanism of $T$ cell activation within the rheumatoid joint remains controversial, as both specific and non-specific mechanisms have been proposed. Specific activation could be through recognition of antigens within the joint, and non-specific activation through exposure of $T$ cells to the inflammatory milieu of cytokines, leading to polyclonal activation.

One approach to determine if there has been antigen specific activation of a particular $T$ cell is to look for clonal expansion of $T$ cells bearing a unique $T$ cell receptor (TCR). Alternatively, if the antigen is known, the precursor frequency of an antigen-specific $T$ cell response may be established. However, even when the antigen responsible is known, the precursor frequency may be too low to be revealed by conventional methods of detecting clonality. Polymerase chain reaction (PCR) based techniques now permit us to analyse small samples with greater sensitivity, in order to establish if clonal expansion has taken place at a sequence level.

Recent studies on the usage of TCRs in RA have shown that joint $T$ cells have frequently undergone clonal expansion, as detected by Southern blotting, ${ }^{3}$ and by the presence of dominant clonotypes among TCR mRNA transcripts produced by joint $\mathrm{T}$ cells. ${ }^{4-6}$ There is, however, less consensus on whether there is preferential utilisation of particular $\mathrm{V} \alpha$ or $\mathrm{V} \beta$ gene families by $\mathrm{T}$ cells in the joint. ${ }^{7}$

In this study, we have used the PCR to amplify small quantities of synovial TCR cDNA isolated from CD4 $T$ cells, which recognise antigen presented in the context of HLA-DR molecules. We chose to analyse the $\mathrm{V} \beta 12$ and V $\beta 14$ families in particular, as we frequently found their expression to be increased within the joint in preliminary experiments. The clonotypic composition was then analysed by DNA sequencing to determine if TCR expression was oligo- or polyclonal. Further analysis was undertaken in two patients to ascertain if TCR expression changed qualitatively over the course of disease.

\section{Materials and methods \\ PATIENTS}

We studied three patients with clinical changes typical of rheumatoid arthritis, diagnosed according to the American College of Rheumatology criteria. ${ }^{8}$ One was male and two female, with disease durations of one, four, and 18 years, respectively. Synovial fluids were obtained at the time of arthrocentesis and were used immediately, without prior in vitro expansion. The two patients who were studied longitudinally had repeated aspirations from the same knee, one performed after an interval of three months, and the other after nine months.

\section{CELL ISOLATION AND SEPARATION}

Synovial fluid of RA patients was collected in preservative free heparin $(5 \mathrm{U} / \mathrm{ml})$ with 3000 units of hyaluronidase (CP pharmaceuticals, Wrexham, Clwyd, UK) to prevent clot formation. Mononuclear cells were isolated by density gradient centrifugation on Ficoll 
(Lymphoprep, Nycomed, Oslo). CD4 T cells were isolated from the mononuclear cell population using magnetic beads to which antiCD4 monoclonal antibody was covalently coupled (Dynalbeads, Dynal AS, Oslo, Norway). Mononuclear cells were resuspended in phosphate buffered saline (PBS) with $1 \%$ fetal calf serum (FCS) and magnetic beads were added to the cells at a ratio of $3: 1$. The selected cells were washed in PBS with $2.5 \%$ FCS, and resuspended in $1 \times \mathrm{RPMU} / 1 \% \mathrm{FCS}$ for detachment, performed using Detachbeads (Dynal AS). The purity of the isolated cell population was ascertained using antibodies to CD4 and to CD8 in cytofluorimetric analyses, and was shown to be greater than $98 \%$ CD4 cells. Cell viability was ascertained using trypan blue exclusion, and was greater than $90 \%$. cDNA was synthesised from the isolated cells using the guanidinium thiocyanate method. More than $4 \times 10^{6} \mathrm{CD} 4 \mathrm{~T}$ cells were isolated in each experiment.

SEQUENCING OF V $\beta$ NDJ REGIONS

V $\beta$ mRNA transcripts were amplified by PCR and then sequenced to determine the clonotypic composition. Approximately $5 \mu \mathrm{g}$ of total RNA was used in each reverse transcriptase reaction, with $50 \mathrm{U}$ of avian myeloblastoma virus reverse transcriptase (Life Technologies, Paisley, UK) and $100 \mathrm{ng}$ of $\mathrm{C} \beta$ specific oligonucleotide (5' CTCTTGACCATGGCCATAAC-3'). Aliquots of the reaction product were then taken for PCR amplification of the $V \beta 12$ and $V \beta 14$ families. The sequences of the primers used and their relative positions in the TCR $\beta$ cDNA transcript have been described previously. ${ }^{6}$ For V $\beta 14$ sequences, a V $\beta 14$ specific primer was designed to give a Pst 1 restriction site (5' GTCTGCAGAAAAGAGAAGAGGAAT3') to facilitate cloning. Amplified V $\beta$ products were purified using the Magic DNA clean up system (Promega, Madison, WI, USA). The products were then ligated into double stranded M13mp18 DNA which was restricted with the appropriate restriction endonuclease. The $\mathrm{V} \beta 12$ products were blunt end ligated. Following transformation and plating, libaries of more than 200 recombinant plaques were obtained from each transformation. Recombinant phages were identified by screening of filter lifts which were transferred onto Hybond $\mathrm{N}$ membranes (Amersham, UK) with V $\beta 14$ and V $\beta 12$ probes. Sequencing of positive plaques was performing using the dideoxy chain termination method using modified T7 DNA polymerase (Sequenase, US Biochem, Cleveland, OH, USA) and run on $6 \%$ polyacrylamide gels. Nucleotide sequences were translated to obtain the amino acid sequence of the NDJ region in order to identify the clonotype of TCR transcript. A dominant clonotype was said to present within a compartment if the same unique sequence (at the nucleotide level) was found more than once within that compartment.

\section{Results}

MULTIPLE EXPANDED TCR $\beta$ CLONOTYPES

WITHIN SYNOVIAL CD4 T CELLS

Tables 1 and 2 give details of the sequences obtained. At least 25 separate plaques were isolated and sequenced from each library.

Table 1 foining region sequences of dominant clonotypes present among joint CD4 T cells expressing VB12 and VB14 receptors

\begin{tabular}{|c|c|c|c|c|c|c|c|}
\hline \multicolumn{3}{|l|}{ Sequence } & \multirow{2}{*}{$\begin{array}{l}\text { No/Frequency } \\
\\
6(23 \%) \\
7(27 \%) \\
2(7 \cdot 6 \%)\end{array}$} & \multicolumn{3}{|l|}{ Sequence } & \multirow{2}{*}{$\begin{array}{c}\text { No/Frequency } \\
\\
11(36 \cdot 7 \%) \\
12(40 \%) \\
2(6 \cdot 7 \%)\end{array}$} \\
\hline $\begin{array}{l}\text { Patient } 1 \\
V \beta 12(n=26) \\
\text { YFCAIS } \\
\text { YFCATS } \\
\text { YFCAIS }\end{array}$ & $\begin{array}{l}\text { DPGQGED } \\
\text { STGDG } \\
\text { GVDSGRPSPQ }\end{array}$ & $\begin{array}{l}\text { GYF1.2 } \\
\text { NQP1.5 } \\
\text { YF2.7 }\end{array}$ & & $\begin{array}{c}V \beta 14(n=30) \\
\text { YFCASS } \\
\text { YFCASS } \\
\text { YFCASS }\end{array}$ & $\begin{array}{l}\text { LSQYEVGE } \\
\text { LTSPPAGF } \\
\text { FDRAR }\end{array}$ & $\begin{array}{l}\text { ETQ2.5 } \\
\text { DTI1·3 } \\
\text { EKL1·4 }\end{array}$ & \\
\hline $\begin{array}{l}\text { Patient } 2 \\
\text { V } 12 \text { (1 st sam } \\
\text { YFCAIS } \\
\text { YFCAIS } \\
\text { YFCA } \\
\text { YFCAIS } \\
\text { YFCAIS }\end{array}$ & $\begin{array}{l}\text { Dle) }(n=28) \\
\text { ESSN } \\
\text { EPSVDR } \\
\text { SGRGLAMA } \\
\text { TGDH } \\
\text { EDV }\end{array}$ & $\begin{array}{l}\text { TEA1·1 } \\
\text { GYT1 } 12 \\
\text { TF1 } 2 \\
\text { EQF2 } 2 \cdot 1 \\
\text { YEQ2 } 7\end{array}$ & $\begin{array}{l}6(21 \cdot 4 \%) \\
3(10 \cdot 7 \%) \\
2(7 \%) \\
2(7 \%) \\
1(3 \cdot 5 \%)\end{array}$ & $\begin{array}{l}V \beta 14 \text { (1st sam } \\
\text { YFCASS } \\
\text { YFCASS } \\
\text { YFCASS } \\
\text { YFCASS } \\
\text { YFCASS } \\
\text { YFCAS }\end{array}$ & $\begin{array}{l}\text { ple })(n=28) \\
\text { RDSH } \\
\text { LLGTRG } \\
\text { RGAG } \\
\text { PRGNQ } \\
\text { FQGYT } \\
\text { GRQGNG }\end{array}$ & $\begin{array}{l}\text { NEQ2 } 1 \\
\text { NEQ2.1 } \\
\text { YNE2 } 1 \\
\text { QHF1.5 } \\
\text { GEL2 } 2 \cdot 6 \\
\text { NQP1.5 }\end{array}$ & $\begin{array}{l}6(21 \cdot 4 \%) \\
5(17 \cdot 8 \%) \\
2(7 \%) \\
2(7 \%) \\
1(3 \cdot 5 \%) \\
1(3 \cdot 5 \%)\end{array}$ \\
\hline $\begin{array}{l}\text { VB12 (2nd sam } \\
\text { YFCAIS } \\
\text { YFCAIS } \\
\text { YFCA } \\
\text { YFCAIS } \\
\text { YFCAIS } \\
\text { YFCAIS }\end{array}$ & $\begin{array}{l}\text { iple) }(n=28) \\
\text { GQTN } \\
\text { PERVA } \\
\text { SGRGIG } \\
\text { ASGSG } \\
\text { VDRVSGS } \\
\text { ESIGG }\end{array}$ & $\begin{array}{l}\text { YGY1 } 2 \\
\text { DTQ2.3 } \\
\text { GYT1 } 12 \\
\text { TDT2 } 3 \\
\text { FGS1·2 } \\
\text { TDT2 } 2\end{array}$ & $\begin{array}{l}2(7 \%) \\
2(7 \%) \\
2(7 \%) \\
2(7 \%) \\
2(7 \%) \\
2(7 \%)\end{array}$ & $\begin{array}{l}\text { VB14 (2nd sam } \\
\text { YFCASS } \\
\text { YFCASS } \\
\text { YFCASS } \\
\text { YFCASS } \\
\text { YFCASS } \\
\text { YFCAS }\end{array}$ & $\begin{array}{l}l p l e)(n=28) \\
\text { FQGYT } \\
\text { PHGQR } \\
\text { YGGRTN } \\
\text { PRPPLARDS } \\
\text { PRGQSE } \\
\text { GRQGNG }\end{array}$ & $\begin{array}{l}\text { GEL2.6 } \\
\text { ETQ2.5 } \\
\text { YGY1.2 } \\
\text { YNE2.1 } \\
\text { HFG1.5 } \\
\text { NQP1.5 }\end{array}$ & $\begin{array}{c}10(35 \cdot 7 \%) \\
2(7 \%) \\
2(7 \%) \\
2(7 \%) \\
2(7 \%) \\
1(3 \cdot 5 \%)\end{array}$ \\
\hline \multirow{2}{*}{\multicolumn{2}{|c|}{$\begin{array}{l}\text { Patient } 3 \\
V \beta 12 \text { (not done) }\end{array}$}} & & & $\begin{array}{l}\text { VB14 (1st sam } \\
\text { YFCASS } \\
\text { YFCAS } \\
\text { YFCASS }\end{array}$ & $\begin{array}{l}\text { le) }(n=25) \\
\text { PLGD } \\
\text { ISDRLSN } \\
\text { SGLS Y }\end{array}$ & $\begin{array}{l}\mathrm{EKL1} \cdot 4 \\
\mathrm{EAF} 1 \cdot 1 \\
\mathrm{EQ} 2 \cdot 7\end{array}$ & $\begin{array}{c}13(52 \%) \\
2(8 \%) \\
2(8 \%)\end{array}$ \\
\hline & & & & $\begin{array}{l}V \beta 14 \text { (2nd sam } \\
\text { YFCASS } \\
\text { YFCASS } \\
\text { YFCASS } \\
\text { YFCASS } \\
\text { YFCASS }\end{array}$ & $\begin{array}{l}\text { ple) }(n=26) \\
\text { LSGTLG } \\
\text { RTPH } \\
\text { SRTSGRVS } \\
\text { LRPQGRS } \\
\text { LGGSS }\end{array}$ & 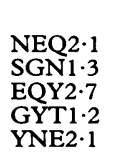 & $\begin{array}{l}2(7 \cdot 7 \%) \\
2(7 \cdot 7 \%) \\
2(7 \cdot 7 \%) \\
2(7 \cdot 7 \%) \\
2(7 \cdot 7 \%)\end{array}$ \\
\hline
\end{tabular}

$\mathrm{n}=$ Total number of sequences analysed for each $\mathrm{V}$ family studied. The nucleotide sequences were translated and shown in the single letter amino acid code, and only the last six amino acids of the $\mathrm{V}$ segment and the first three amino acids of the J segment single letter amino acid code, and only the last six amino acids of the $V$ segment and the first three amino acids of the J segment
utilised are given. The number of times a clonotype was present within the sample is shown, with frequency in \%. Other clonotypes utilised are given. The number of times a clonotype was presen
which only occurred once within the sample are not shown. 
Table 2 Comparison of published NDF sequences of dominant VB14 clonotypes of synovial origin identified to date in rheumatoid arthritis and seropositive juvenile rheumatoid arthritis

\begin{tabular}{|c|c|c|c|}
\hline NDf sequence & & Frequency & Reference \\
\hline $\begin{array}{l}\text { YFCASS LSRP } \\
\text { YFCASS LYGTRN } \\
\text { YFCASS TG } \\
\text { YFCAS NPGGV } \\
\text { YFCASS PRGAY }\end{array}$ & $\begin{array}{l}\text { DTQ2·3 } \\
\text { TQY2 } 2 \cdot 3 \\
\text { NTEAF } 1 \cdot 1 \\
\text { NTEA } 1 \cdot 1 \\
\text { TQY } 2 \cdot 3\end{array}$ & $\begin{array}{l}11 / 18 \\
2 / 18 \\
13 / 21 \\
7 / 22 \\
3 / 22\end{array}$ & $\begin{array}{l}4 \\
4 \\
4 \\
4 \\
4\end{array}$ \\
\hline $\begin{array}{l}\text { YFCASS LGGAV } \\
\text { YFCASS LASGGAV } \\
\text { YFCASS LSFGGRMA }\end{array}$ & $\begin{array}{l}\text { SYN2 } 1 \\
\text { SYN2 } 1 \\
\text { NEQ2 } 1\end{array}$ & $\begin{array}{l}2 / 7 \\
2 / 7 \\
6 / 6\end{array}$ & $\begin{array}{l}10 \\
10 \\
10\end{array}$ \\
\hline YFCASS PQGAVF & YGY1·2 & $16 / 30$ & 6 \\
\hline $\begin{array}{l}\text { YFCAS GSPDAAGW } \\
\text { YFCASS LMAEYNS } \\
\text { YFCASS LNNS } \\
\text { YFCASS RGLN }\end{array}$ & $\begin{array}{l}\text { TDT2 } 2 \cdot 3 \\
\text { PL1·6 } \\
\text { YNE2 } 11 \\
\text { SNQ } 1 \cdot 5\end{array}$ & $\begin{array}{l}16 / 24 \\
9 / 21 \\
3 / 29 \\
11 / 33\end{array}$ & $\begin{array}{l}9 \\
9 \\
9 \\
9\end{array}$ \\
\hline
\end{tabular}

See table 1 for explanations of the method of data presentation. The sources of the sequences cited are listed in the references shown. Only sequences which constituted $>10 \%$ of the sample analysed are listed, except for reference 10, where the sample size was only seven in one analysis.

V $\beta 12$ and V $\beta 14$ families were analysed in patient 1 (white female, disease duration 18 years, HLA DR1/4), and patient 2 (West Indian female, disease duration four years, HLA DR3/5). V $\beta 14$ sequences only were studied in patient 3 (white male, disease duration one year, HLA DR3/3). In patients 2 and 3, synovial fluid was obtained from the same knee on two separate occasions. More than $90 \%$ of the sequences obtained were amenable to interpretation, and a total of 219 sequences was analysed.

The initial sample from each patient showed the presence of multiple dominant clonotypes. However, the frequencies of individual dominant clonotypes were highly variable, ranging from $7 \%$ of the sequences sampled to $52 \%$.

The results obtained from patient 1 showed three dominant clonotypes present in the V $\beta 12$ population, and three among V $\beta 14$ transcripts (table 1). Four of these six dominant clonotypes were found in high frequency (more than $20 \%$ of the total number of transcripts analysed), and accounted for more than $50 \%$ of the total number of sequences analysed.

In the first sample obtained from patient 2 , four dominant clonotypes were present among 28 V $\beta 12$ transcripts, and four among the 28 V $\beta 14$ transcripts (table 1). Again, the dominant clonotypes comprised a large proportion of the sequences found.

The first sample from patient 3 revealed that more than $50 \%$ of the V $\beta 14$ transcripts were of one clonotype, with two others present in low frequency (table 1).

ALTERATION IN TCR $\beta$ CLONOTYPIC COMPOSITION DURING THE COURSE OF DISEASE Patient 2 had recurrence of synovitis in the same knee after a nine month interval. A change in the composition and sequences of $V \beta 12$ and V $\beta 14$ clonotypes was found between the two samples obtained (table 1). Essentially, none of the clonotypes found in the initial aspirate was present in the second, with the exception of two V $\beta 14$ clonotypes. One was present singly in each sample (YFCASGRQNGNP), while the other (YFCASSFQGYTGE$\mathrm{LF}$ ), found once in the first aspirate, formed the majority of the transcripts present in the second aspirate. Among $\mathrm{V} \beta 12$ transcripts, none of the four dominant clonotypes seen in the first sample was present in the second sample, which had a different clonotype population.

Similar results were observed in patient 3 , who was re-examined after a three month interval (table 1). In the first aspirate, the clonotypic sequence FCASSPLGD represented more than $52 \%$ of the sequences present. In the second aspirate, all the dominant clonotypes present were of low frequency.

\section{Discussion}

This study aimed to answer two questions: first, are synovial CD4 T cells activated (and if so, is the activation oligoclonal or polyclonal), and second, does the TCR clonotypic composition change during the course of RA within the same joint? Previous studies have reported clonal expansion of TCR $\beta$ transcripts in RA and in patients with seropositive juvenile chronic arthritis (JCA), when unfractionated $\mathrm{T}$ cell populations were analysed..$^{4-6} 9$

Our present findings, although based only on a small sample of patients, confirmed that there are multiple dominant clonotypes present within joint CD4 T cells. We chose to analyse only two V $\beta$ families using this sequencing strategy, and found dominant clonotypes in each. We defined a dominant clonotype in this study as any sequence present more than once within a particular sample. This was based on calculation of the number of different possible transcripts within one $V \beta$ family to be of the order of $3.8 \times 10^{6}$ : we assumed that the potential TCR $\alpha \beta$ repertoire can generate $10^{15}$ different receptors, ${ }^{10}$ and that the number of different TCR $\beta$ chains may therefore be as great as $10^{7}$ (the total repertoire being the combinatory potential of all existing TCR $\alpha$ and $\beta$ chains). Assuming equal utilisation of each $V \beta$ family in the peripheral repertoire, each family can contain up to $3.8 \times 10^{6}$ different cDNA transcripts (26 distinct $V \beta$ families have been identified to date).

Our results suggest that a large number of dominant clonotypes would be found to be present in RA synovial fluid if $V \beta$ transcripts from each family were to be sequenced. The significance of dominant clonotypes which are present at a frequency less than $10 \%$ is uncertain, but when a clonotypic sequence forms more than $20 \%$ of the entire sample analysed, it indicates that local activation of a specific clone of $T$ cell has taken place, resulting in increased RNA transcription from that clone. Polyclonal activation of $T$ cells by IL-2, phytohaemagglutinin and superantigen have never revealed such clonal dominance at the sequence level (S Hall, personal communication). These findings therefore 
indicate that CD4 $\mathrm{T}$ cells in the joint are activated in an oligoclonal manner probably following antigen recognition.

We do not believe these results to be artefacts arising from the methods used. Our previous control studies $^{6}$ on sequencing of TCR transcripts from peripheral blood did not show an obvious clonal dominance. Furthermore, sequencing of the $\mathrm{V} \beta 14$ transcripts of peripheral blood CD4 $\mathrm{T}$ cells (30 sequences) from patient 3 showed that all the sequences were entirely different from one another, and no dominant clonotype was observed (data not shown).

Our longitudinal studies in two patients showed that the clonotypic composition within the joint was not static. Large changes in the sequences present were found within the same joint. These results imply that the process of rheumatoid synovial inflammation is dynamic. We cannot exclude an effect of corticosteroids in altering the composition of the $T$ cell population, as they were given at the time of the initial aspirate, but the finding of a changed clonotypic population indicates that $T$ cells bearing different TCRs are capable of participating in synovial inflammation, and they may be recognising different antigens. These results are very different from those obtained by Grom et $a l^{9}$ who found the same TCR V 14 clonotype in multiple synovial specimens over time from a patient with seropositive JCA. Their finding is more reminiscent of a malignant process involving a monoclonal $T$ cell population than of chronic inflammation.

It is of interest that dominant clonotypes within V $\beta 14$ expressing $T$ cells have now been found in a number of different studies. ${ }^{4911}$ What mechanism may link this phenomenon with synovial inflammation? Comparison of the published sequences (table 2) reveals them to be quite dissimilar over the NDJ region which plays a direct role in TCR recognition of the peptide MHC complex; $;^{12}$ this suggests that they have different fine specificities. However, V $\beta 14$ itself may be able to confer a degree of antigenic specificity: frequent usage of $\mathrm{V} \beta 8.2$ sequences in the recognition of myelin basic protein in experimental allergic encephalomyelitis has been reported. ${ }^{13}$ Alternatively, prior superantigen activation of Vß14-expressing $T$ cells may predispose them to subsequent antigen activation, as has been proposed by Kotzin. ${ }^{4}$

In conclusion, our results indicate that $\mathrm{RA}$ synovial CD4 $\mathrm{T}$ cells contain a number of different oligoclonally activated subpopulations, which may be responding to multiple antigens. The population of activated $T$ cells does alter during the course of disease within a particular joint. These results may explain why therapies directed against $T$ cells have not been as successful as originally envisaged, and suggest that continuous suppression of $T$ cell activation would be required to control the local disease effectively

The work was funded by grants from the Arthritis and Rheumatism Council, and the Wellcome Trust, UK. HK is supported by a scholarship from the Islamic Republic of Iran, Supported by a scholarship from

To obtain the nucleotide and amino acid sequences of all the transcripts obtained, please contact the corresponding author

1 Burmester G R, Yu D T Y, Irani A-M, Kunkel H G, Winchester R J. Ia $+\mathrm{T}$ cells in synovial fluid and tissues of patients with rheumatoid arthritis. Arthritis Rheum 1981; 24: 1370-6.

2 Nepom G T, Hansen J A, Nepom B S. The molecular basis for HLA class II associations with rheumatoid arthritis. for HLin Immunol 1987; 7: 1-7.

3 Miltenburg A M, van Laar J M, Daha M R, de-Vries R R van den Elsen P, Breedveld F C. Dominant T-cel receptor beta-chain gene rearrangements indicate clonal expansion in the rheumatoid joint. Scand f Immunol 1990 31: $121-6$

4 Paliard X, West S G, Lafferty J A, et al. Evidence for the effects of a superantigen in rheumatoid arthritis. Science 1991; 253: 325-9.

5 Uematsu Y, Wege H, Straus A, et al. The T-cell-receptor repertoire in the synovial fluid of a patient with rheumatoid arthritis is polyclonal. Proc Natl Acad Sci USA 1991; 88: 8534-8.

6 Lunardi C, Marguerie C, So A K. An altered repertoire of $\mathrm{T}$-cell receptor $\mathrm{V}$ gene expression by rheumatoid synovial T-cell receptor V gene expression by rheumatoid synovial

7 Marguerie C, Lunardi C, So A K. PCR-based analysis of he TCR repertoire in human autoimmune diseases. Immunol Today 1992; 13: 336-8.

8 Arnett F C, Edworthy S M, Bloch D A, et al. The American Rheumatism Association 1987 revised criteria for the classification of rheumatoid arthritis. Arthritis Rheum 1988; 31: 315-24.

9 Grom A A, Thompson S D, Luyrink L, Passo M, Choi E, Glass D N. Dominant T-cell-receptor b chain variable region $\mathrm{Vb} 14+$ clones in juvenile rheumatoid arthritis. Proc Natl Acad Sci USA 1993; 90: 11104-8.

10 Davis M M, Bjorkman P J. T Cell antigen receptor genes and T-cell recognition. Nature $1988 ; 334: 395-402$

11 Howell M D, Diveley J P, Lundeen K A, et al. Limited T-cell receptor beta-chain heterogeneity among interleukin 2 receptor-positive synovial $T$ cells suggests a role for croc Natl Acad Sci USA 1991; 88: 10921-5.

12 Jorgensen J L, Esser U, Fazekas-de-St-Groth B F, Reay P A, Davis M M. Mapping T-cell receptor-peptide contacts by variant peptide immunization of single-chain transgenics. Nature 1992; 355: 224-30.

13 Zamvil S, Lee N E, Moore A C, et al. Predominant expression of a $\mathrm{T}$ cell receptor V-beta gene subfamiliy in autoimmune encephalomyelitis. F Exp Med 1988; 167: 1586-96. 